\title{
THE UPPER PLEISTOCENE OF SÃO FRANCISCO DO SUL ISLAND COASTAL PLAIN: GEOMORPHOLOGIC, SEDIMENTOLOGIC AND EVOLUTIVE ASPECTS
}

\author{
Norberto Olmiro Horn Filho ${ }^{1}$ and Daniel Higueras Simó ${ }^{2}$
}

Universidade Federal de Santa Catariana - UFSC

Departamento de Geociências

(Campus UFSC, Trindade, P.O. Box 476, 88.040-970 Florianópolis, SC, Brasil)

${ }^{1}$ horn@cfh.ufsc.br; ${ }^{2}$ simodaniel@hotmail.com

\begin{abstract}
A B S T R A C T
The upper Pleistocene deposits ( $\pm 120 \mathrm{ky}$ BP) outcrop in several coastal plains throughout the Brazilian coast. The occurrences in Santa Catarina State - Northern coast, where São Francisco do Sul Island is located are included in this context. The Pleistocene deposits which have marine and lagoon origin on the base and eolic origin on the top, characterize typical barrier island confined to crystalline basement elevations. The deposits outcrop on the central sector of São Francisco do Sul Island, close to the coastline, reaching up to $6 \mathrm{~km}$ of width and have variable heights from 12 to $17 \mathrm{~m}$ in elevations and 10 to $12 \mathrm{~m}$ in depressions. The geologic contact with the others coastal plain unities are interdigited and/or abrupt through scarps well defined that reach up to $4 \mathrm{~m}$ of vertical fall. The geomorphologic features consist in terraces exhibiting horizontal and undulated surface, dominating sandy sediments, fine to medium, well sorted, constituted by quartz and heavy minerals. These deposits were formed in higher sea level $(8 \pm 2 \mathrm{~m})$, between 18 to $120 \mathrm{ky} \mathrm{BP}$, during regressive phase of the Sangamonian - Yarmoutian maximum transgression/regression, which is correlated to the interglacial Riss/Wurm, corresponding in Brazil to Cananéia transgression (SP), Penultimate transgression $(B A)$ or barrier III $(R S)$.
\end{abstract}

\section{RESUMO}

Os depósitos do Pleistoceno superior ( \pm 120 ka AP) afloram em diversas planícies costeiras ao longo do litoral brasileiro, incluindo as ocorrências no setor Norte do litoral do Estado de Santa Catarina, onde se encontra localizada a ilha de São Francisco do Sul. Os sedimentos do Pleistoceno superior, de origem marinho praial e lagunar na base e eólica no topo, representam típicas ilhas - barreiras confinadas às elevações do embasamento cristalino. Os depósitos afloram no setor central da ilha de São Francisco do Sul, próximos à linha de costa atingindo até $6 \mathrm{~km}$ de largura e altitudes variáveis de 12 a $17 \mathrm{~m}$ nas elevações e 10 a $12 \mathrm{~m}$ nas depressões. O contato geológico com as demais unidades da planície costeira é interdigitado e/ou brusco através de falésias bem definidas que alcançam até $4 \mathrm{~m}$ de desnível vertical. As formas dominantes dos depósitos são terraços de superfície plana a levemente ondulada, predominando grãos arenosos, finos a médios, selecionados, constituídos de quartzo e minerais pesados. Os depósitos foram formados em um nível marinho mais elevado que o atual $(8 \pm 2 \mathrm{~m})$, entre 18 e $120 \mathrm{ka} \mathrm{AP}$, durante a fase regressiva do máximo da transgressão/regressão Sangamoniana - Yarmoutiana, correlacionada ao período interglacial Riss/Wurm, correspondendo no Brasil à transgressão Cananéia (SP), Penúltima transgressão (BA) ou barreira III (RS).

Descriptors: Pleistocene, Coastal plain, Geomorphology, Paleogeography.

Descritores: Pleistoceno, Planície costeira, Geomorfologia, Paleogeografia.

\section{INTRODUCTION}

In the last years, a considerable number of studies about coastal plains has been performed, looking for solutions of environmental problems which are produced by tourism and urban occupation. It is inserted in this context, São Francisco do Sul Island which is located in Santa Catarina State Northern coast (HORN FILHO \& DIEHL, 1994), between $26^{\circ} 09^{\prime} 42^{\prime \prime}$ to $26^{\circ} 27^{\prime} 05^{\prime \prime} \mathrm{S}$. and $48^{\circ} 29^{\prime} 38^{\prime \prime}$ to 4842'59”'W. (Fig. 1).

São Francisco do Sul Island presents a triangular shape with $35 \mathrm{~km}$ maximum length and 16 $\mathrm{km}$ maximum width and represents a typical continental island under mixed regimen, influenced hidrodynamically eastward by South Atlantic Ocean; west and northwestward by Babitonga Bay/Estuary and southwestward by Linguado Channel (Fig. 2). 


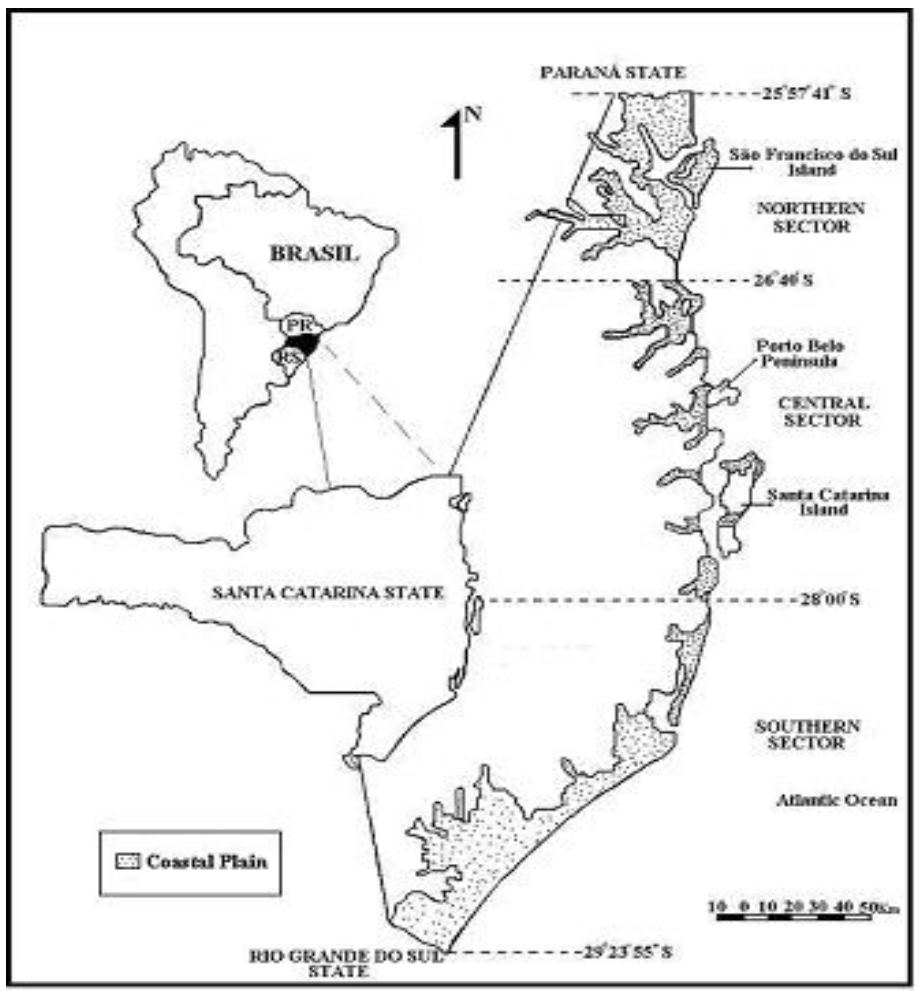

Fig.1. São Francisco do Sul Island location on Santa Catarina coast - Northern sector.

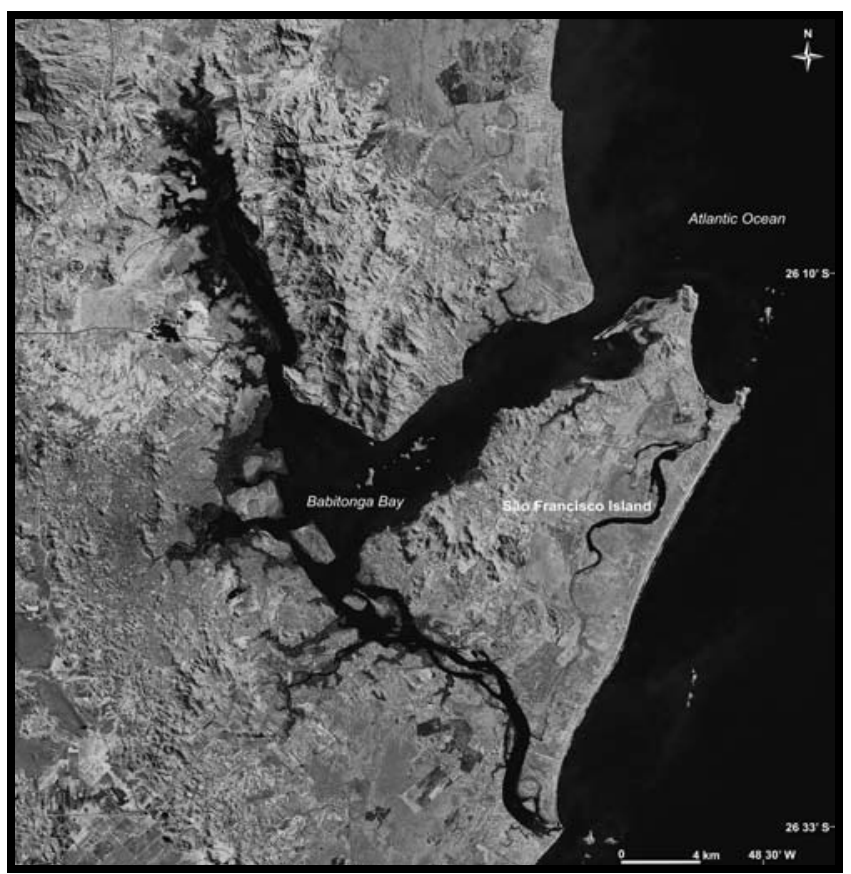

Fig.2. São Francisco do Sul Island adjacent to South Atlantic Ocean and Babitonga Bay. 
The importance of the island is based on its attractive beaches (Enseada, Capri, Itaguaçu, Prainha and Grande) and the economic importance which is unveiled by oil activities and the São Francisco do Sul Harbor (SPERB et al., 2004). On the historical point of view, the island is important because it settles $S a \tilde{o}$ Francisco do Sul City, the third Brazilian older town set up in 1504. The terrestrial access is realized by pavement roads (BR 101 and BR 280), that constitute the actual mechanic embankment mainland - island.

\section{Material and Methods}

This study describes the main geological unities of São Francisco do Sul Island coastal plain and it focus on the mainly upper Pleistocene deposits, the stratigraphic synthesis as well as on petrologic and sedimentologic characteristics of the rocks and Quaternary sediments.

The method comprised: (a) bibliographic revision; (b) photointerpretation; (c) field work; (d) laboratory analyses; (e) compilation of information.

\section{Results}

São Francisco do Sul Island Geology

The geology of São Francisco do Sul Island coastal plain, described by Horn Filho (1997) is constituted by Arquean and Proterozoic rocks from the crystalline system and by associated eluviums. It is also constituted by Quaternary sediments with undifferentiated age from the continental system and Pleistocene and Holocene sediments from the strand plain system (Table 1) (Fig. 3).

The basement is represented by the crystalline system of Santa Catarina shield composed by rocky massifs, isolated elevations and promontories which constitute, from the geomorphologic point of view, the highlands from the meridional sector of serra do Mar in Brazil and the northeast sector of serras do Leste Catarinense in Santa Catarina State (HORN FILHO, 2003). Granites and gneisses are the dominant rocks, followed by schist, quartzite, amphibolites and migmatites, lithologies from the Núcleo Migmatítico de Injeção Polifásica de São Francisco do Sul (SILVA, 1984), integrant of Complexo Tabuleiro (TRAININI et al., 1978).

Weathering processes over and above preexistent rocks, allowed the development of thick eluvial sediments dominantly gneissic and granitic origin. These sediments associated with gravitational streams on the highlands hillsides, constitute colluvial, alluvial fan and fluvial deposits, undifferentiated Quaternary aged, typical of continental system.

Colluviums are composed by mixed particles; sandy, silt and clayey sediments; usually immature and angle shape. Fluvial deposits comprehend channel, meander bar and flood plain sediments. Sand, gravel and boulder dominate channel deposits; sandy and silt-clayey sediments are common among meander bar and flood plain deposits.

In strand plain system, the geological unities from the coastal plain are gathered, which has correlation with the transgressive and regressive events of the South Atlantic, corresponding in chronological order to upper Pleistocene and Holocene epochs (Fig. 4). Represents a plain composed by successive strand plains, shaping a flat and undulate surface, formed by growing of sandy spits, accumulated by alongshore currents or beach ridges originated by waves action (SUGUIO, 1992).

The Pleistocene of the strand plain is characterized by the presence of intertidal marine and lagoon deposits recovered by eolic sediments.

Table 1. São Francisco do Sul Island coastal plain stratigraphy.

\begin{tabular}{lll}
\hline \hline \multicolumn{1}{c}{ Age } & System & \multicolumn{1}{c}{ Geology } \\
\hline Holocene & Strand plain & $\begin{array}{l}\text { Marine deposit } \\
\text { Lagoon deposit } \\
\text { Fluvio-lagoon deposit } \\
\text { Paludal deposit }\end{array}$ \\
& & $\begin{array}{l}\text { Marine deposit } \\
\text { Lagoon deposit }\end{array}$ \\
Upper Pleistocene & Strand plain & Fluvial deposit \\
& & Alluvial fan deposit \\
Undifferentiated Quaternary & Continental & Eluvial and colluvial deposits \\
& & Granitic and metamorphic rocks \\
Pre-Mesozoic & Crystalline &
\end{tabular}




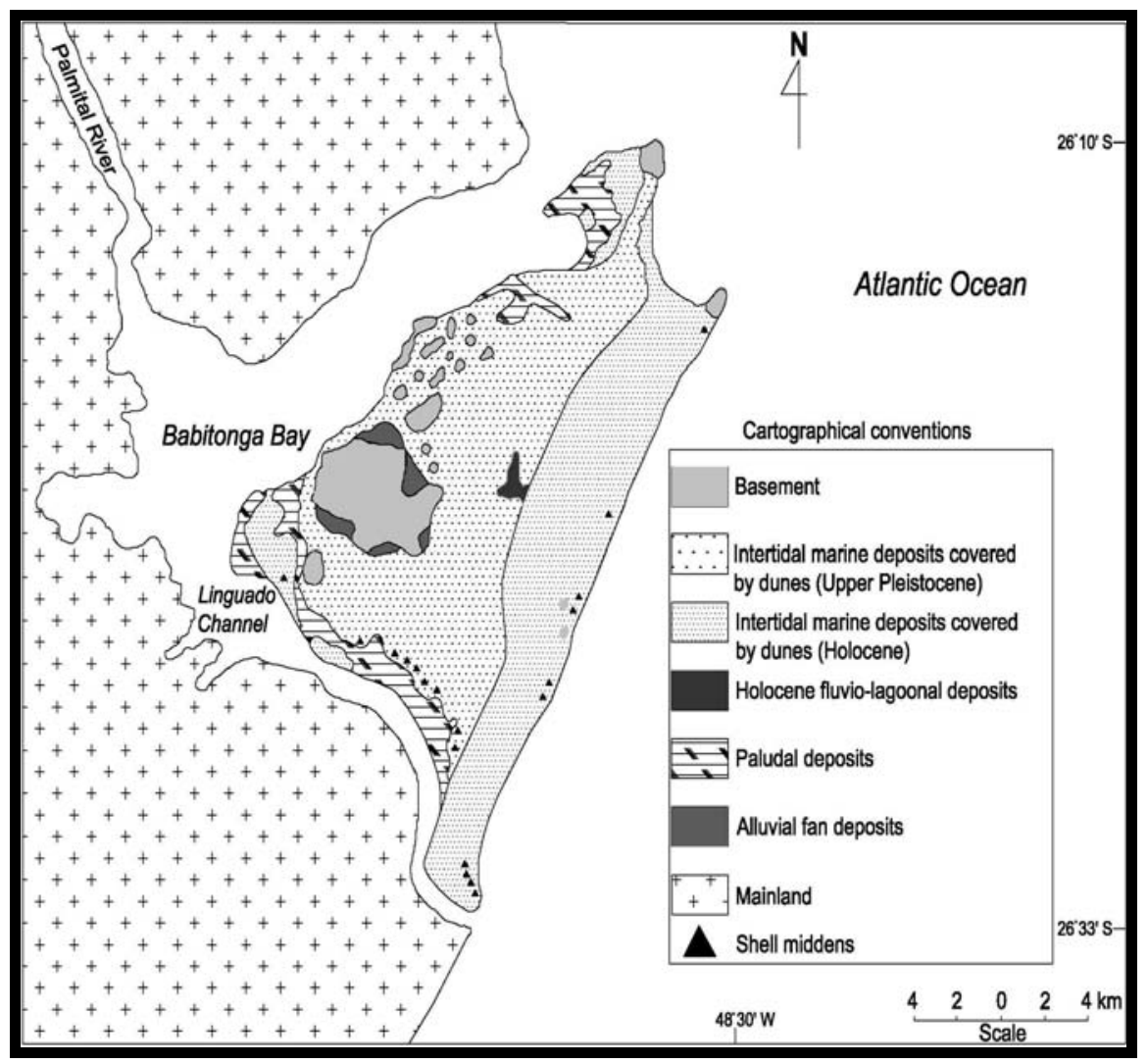

Fig. 3. São Francisco do Sul Island geological coastal plain map.

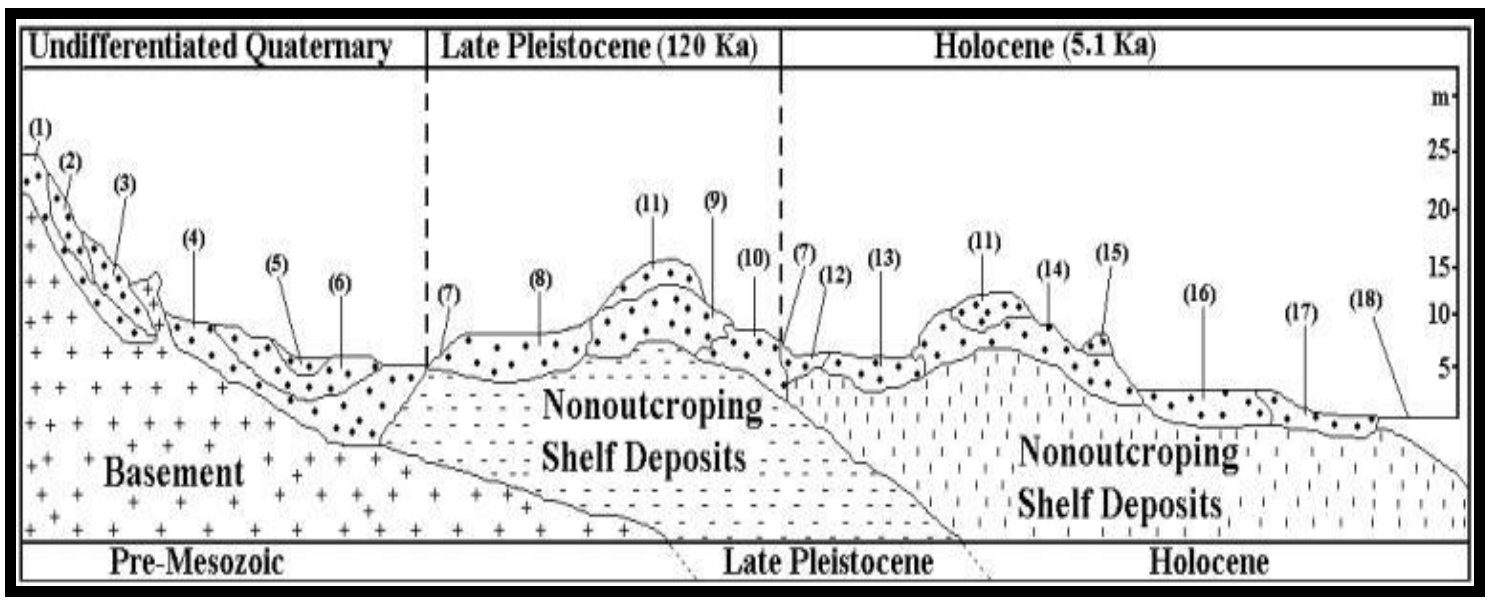

Fig. 4. Geologic and geomorphologic features mapped on the Northern sector of the Santa Catarina State coastal plain, according to Horn Filho et al. (1996). (1) Eluvium's; (2) Colluviums; (3) Alluvial fans; (4) Flood plains; (5) and (12) Fluvial terraces; (6) Marginal dikes; (7) Scarps; (8) and (13) Lagoon terraces; (9) and (11) Littoral dunes; (10) and (14) Marine terraces and beach ridges; (15) Shell-middens; (16) Paludal deposits - mangrove and salt marsh; (17) beaches and (18) mean sea level. 
In Holocene are considered eolic, marine and lagoon deposits, besides of fluvio-lagoon, paludal, estuarine and anthropogenic conchiferous deposits (shell-middens), named "sambaquis".

Aeolic deposits show up barcanoid dunes shaped, active or settled by "restinga" vegetation. In these deposits predominate medium sands, quartzose, rounded and well classified sediments. Intertidal marine and lagoon deposits represent littoral ridges and furrows, with elevations between 4 to $9 \mathrm{~m}$ and composed by fine sandy sediments, moderately to well classified and essentially quartzose grained.

Fluvio-lagoon deposits are resultant from the accumulation of sediments aroused by erosion and transport of particles situated upward, exhibiting flat surface terraces, elongated and constituted by fine sandy sediments and well classified.

Paludal deposits with fine sandy sediments and characteristic vegetation of mangrove and salt marsh represent tide plain sediments in protected areas submerged by high tide and exposed during low tides. Estuarine deposits are composed by fine sandy sediments and silt and clay, proceeding from Babitonga Bay, accumulated in low energy environment with excessive fine load transported in suspension.

The "sambaquis" display conical mounds, with altitudes between 7 to $15 \mathrm{~m}$ and constituted by sandy sediments, carbonaceous shells, besides the biological and archaeological materials. The São Francisco do Sul Island Holocene age is confirmed by presence of shell-middens, whose epoch is similar to other shell-middens found out in other southern Brazilian coastal plains (HORN FILHO et al., 1995).

Along geologic time, granitic and gneissic rocks from the crystalline system were source area of sediments to continental and strand plain systems, reworked later by action of main natural agents that actuate in marine, lagoon and fluvial environments.

On the other hand, the presence of basement elevations was important to configurate the preterit and recent coastline and relative geographical position of the studied area coastal plain Pleistocene and Holocene deposits.

The São Francisco do Sul Island geologic study defined seven paleogeographic stages to the coastal plain since the end of the Pliocene to Holocene regression: (I) Interstage 1 - Pliocene maximum transgression; (II) Stage 2 - Pliocene maximum regression; (III) Interstage and Stage 3 Transgressions and regressions of the lower and medium Pleistocene; (IV) Interstage 4 - Upper Pleistocene maximum transgression; (V) Stage 5 Upper Pleistocene maximum regression; (VI) Interstage 6 - Holocene maximum transgression; (VII) Stage 7 - Holocene maximum regression.
Lately, São Francisco do Sul Island has been submitted to intense tourism development, producing an accelerated fragmentation of its deposits and rocks. Thereby the number of allotments, buildings and residential quarters has increased, masquerading physical and biological characteristics of the main Quaternary deposits. Crystalline rocks, gravel materials, sandy and muddy sediments have been explored arbitrarily and utilized on the civil architecture. The environmental consequences resulting from this exploration have been observed in several places.

The Brazilian Oil Company (PETROBRAS) runs on the island northeast sector, a petroleum station and a pipe-line, buried in the Quaternary deposits. Notwithstanding the alterations resulting from the expansion of São Francisco do Sul coastal plain over the last 60 years and according to Butler (1980), it is still at the final stage of involvement and initial stage of development.

The discerning and maintained development will provide an environmental preservation of $S a \tilde{o}$ Francisco do Sul Island which represents a touristy potential to the Brazilian southeastern coast.

\section{The São Francisco do Sul Island upper Pleistocene}

The upper Pleistocene of São Francisco do Sul coastal plain is represented by two deposits: (1) Intertidal marine deposit recovered by eolic deposit and (2) Lagoon deposit.

The intertidal marine deposit recovered by eolic deposit takes up the higher area exposed in São Francisco do Sul Island coastal plain, between $26^{\circ} 12^{\prime}$ and $26^{\circ} 25^{\prime} \mathrm{S}$, extension of $22 \mathrm{~km}$ (northeast southwest) and medium widths of 7 to $8 \mathrm{~km}$.

The deposits outcrop also in the island northern sector, between João Dias and Ubatuba hills. The mean elevations are between 12 to $16 \mathrm{~m}$, however, in the island central sector $\left(26^{\circ} 15^{\prime} \mathrm{S}\right.$.); a circular terrace of $19 \mathrm{~km}^{2}$ area reaching $25 \mathrm{~m}$ high was observed. The dominant geomorphologic features of these deposits are isolated marine terraces or beach ridges plains, exhibiting a succession of ridges and swales well sketched in terrain and aerial photos (Fig. 5).

These deposits are similar to intertidal beach deposits from the Holocene age, however the inward geographic position related to actual coastline and higher elevations were conclusive to define themselves of Pleistocene age. The beach ridges witnessed the occurrence of regressive Pleistocene last episodes, between 18 to $120 \mathrm{ky} \mathrm{BP}$. 
The Pleistocene coastal sediments are predominantly composed by very fine and fine sands and in some cases, by a small contribution of silt and clay. The sediments are chestnut-brown and yellowish. When rich in ferric oxide, the sediments color turns into more brownish and reddish. Quartzose minerals are dominant and heavy minerals and small rocks fragments are secondary.
The intertidal marine sediments are well sorted, with predominant positive skewness and leptokurtic kurtosis. The aeolic sediments that recovered the marine deposits are constituted by fine and medium sand with $15 \%$ of silt and clay. Between these marine and aeolic deposits, palaeosoil levels and ferruginous layers are found (Fig. 6).

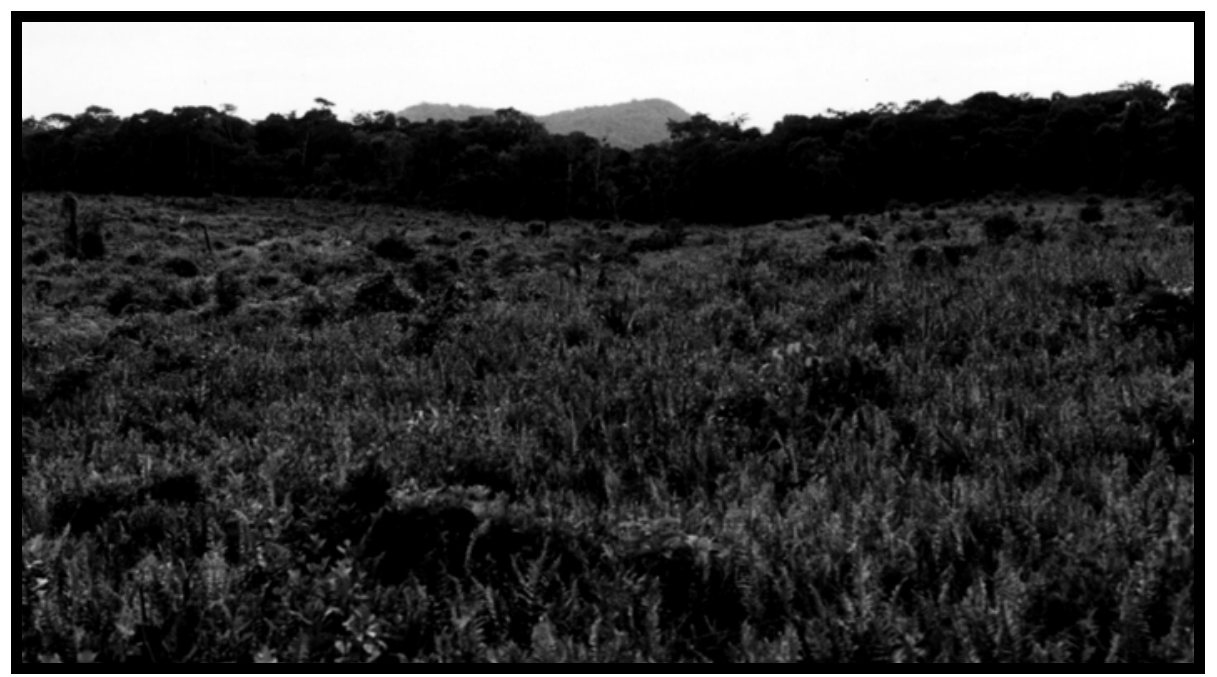

Fig. 5. São Francisco do Sul Island central sector landscape, characterized by Pleistocene beach ridges recovered by typical "restinga" vegetation.

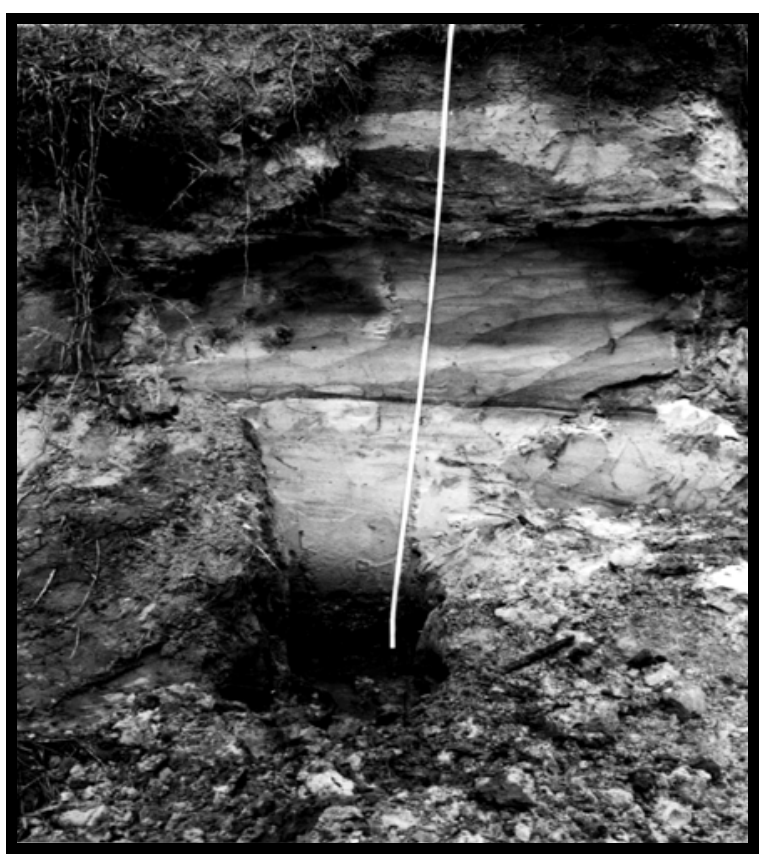

Fig. 6. Stratigraphic section showing Holocene and Pleistocene sediments from aeolic origin, recovering intertidal marine and lagoon upper Pleistocene deposits. 
Horizontal and slightly inclined cross bedding are frequently found in these marine deposits. Bigarella (1975) described dissipative structures in aeolic deposits of Santa Catarina coastal plain, representing undulate features parallel to the original stratification of the dunes caused by infiltration of pluvial waters rich in organic matter and iron colloids.

In some layers the presence of opaque and heavy minerals (hematite, magnetite, and ilmenite) in intertidal marine sediments attests higher hydrodynamic conditions and proximity of the source area (Fig. 7)
The shallow origin of the marine deposits are established by the presence of Callichirus $s p$ that lives in the sub tidal zone burring in sandy sediments, which attest shallow marine environment typical of foreshore and backshore sectors (Fig.8).

The lagoon deposit is composed by silty sand sediments exhibiting typical terraces resulted from colmatation of paleolagoons inlayed between crystalline rocks, colluviums and Pleistocene intertidal/eolic deposits. The terraces are located in western sector of the island, in elevations from 12 to $13 \mathrm{~m}$, displaying plane surface revested usually with secondary "restinga" vegetation.

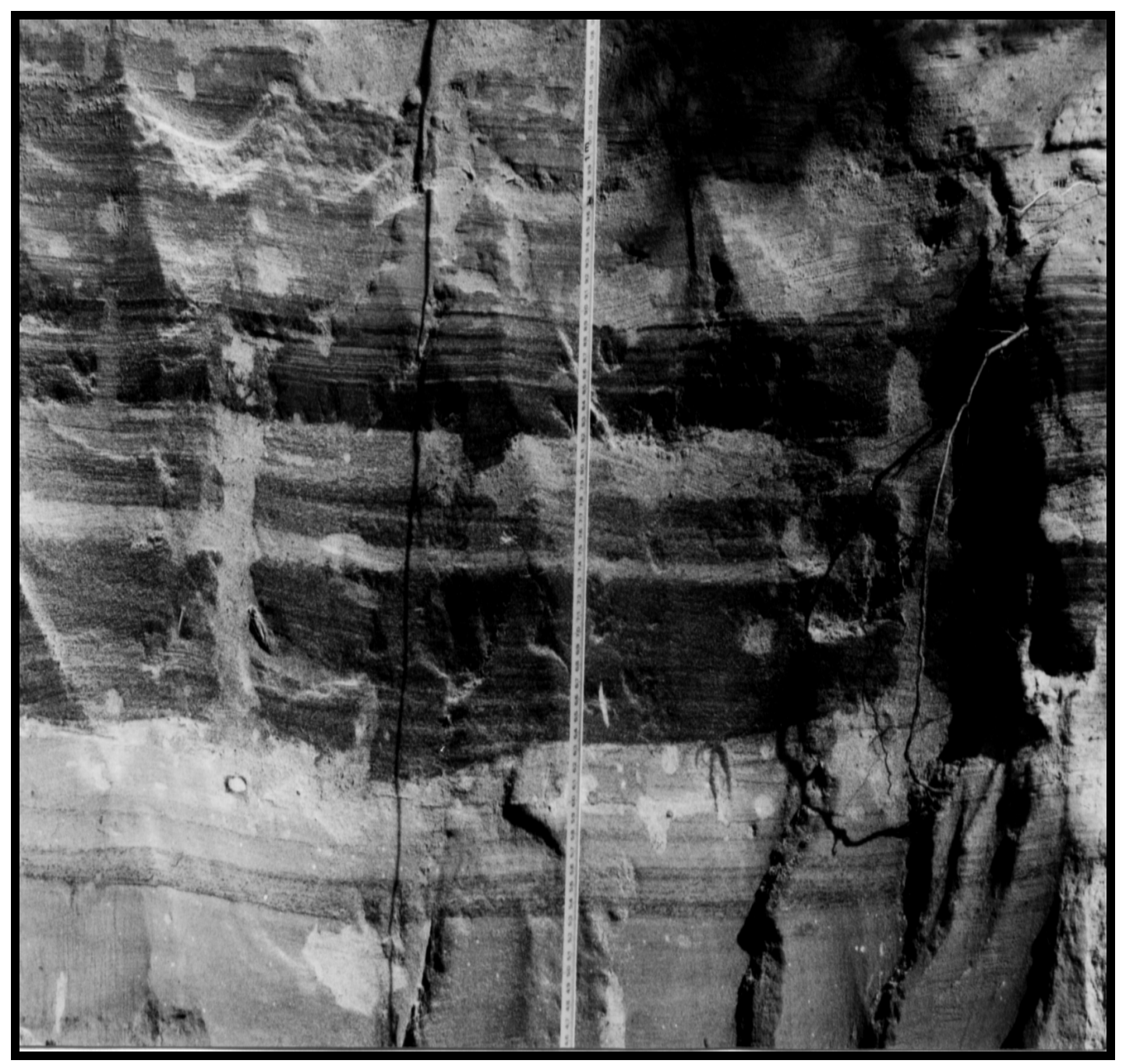

Fig. 7. Horizontal succession of layers constituted by quartzose sands intercalated with sands enriched by opaque and heavy minerals. 


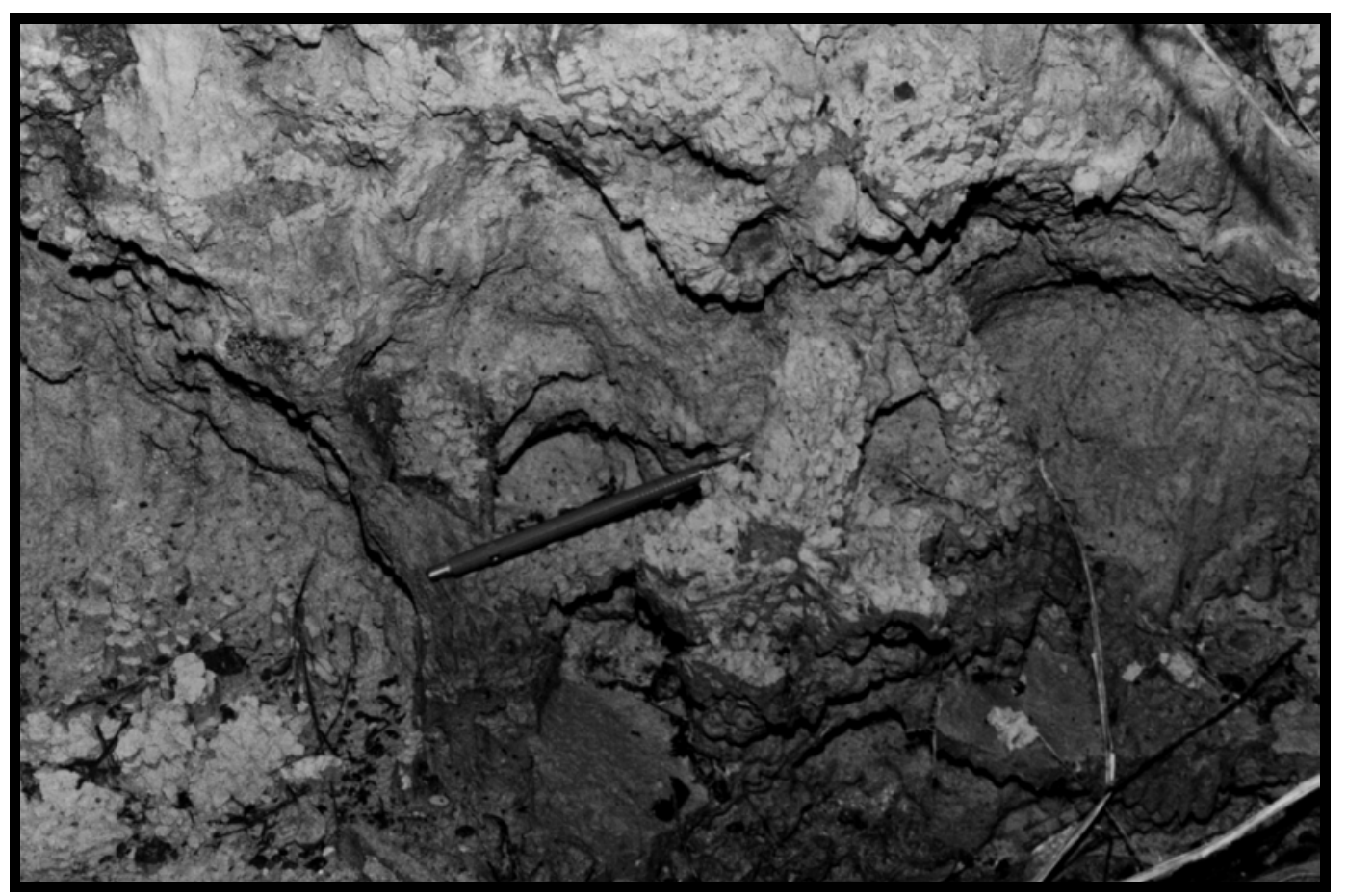

Fig. 8. Presence of Callichirus sp fossil tubes in the marine sediments from the São Francisco do Sul coastal plain upper Pleistocene.

\section{Discussion}

The development and configuration of the upper Pleistocene deposits which outcrop throughout the Brazilian coast, Santa Catarina State and São Francisco do Sul Island coastal plain, would be related to paleoclimatic variations associated to relative sea level oscillations.

The intertidal marine, lagoon and eolic deposits of the upper Pleistocene formed between 18 and 120 ky BP, present usually geomorphologic features as marine and lagoon terraces, beach ridges and fixed paleodunes. These deposits define the last episodes of the Pleistocene in Santa Catarina State (HORN FILHO et al., 1996 and HORN FILHO et al., 1997), which is correlated with other Brazilian coastal plains (BITTENCOURT et al., 1979; VILLWOCK et al., 1986; SUGUIO \& MARTIN, 1986; MARTIN et al., 1988).

The deposits (from 10 to $17 \mathrm{~m}$ above present mean sea level) present very fine and fine sands, well sorted, chestnut-brown and yellowish colored and presence of Callichirus $s p$ fossil tubes, representing geomorphologic, sedimentologic and biologic evidences of these intertidal marine deposits recovered by eolic sediments of Pleistocene and Holocene ages.

The deposits were formed in higher sea level
$(8 \pm 2 \mathrm{~m})$, between 18 and $120 \mathrm{ky} \mathrm{BP}$, during regressive phase of the Sangamonian - Yarmoutian maximum transgression/regression, correlationed to interglacial Riss/Wurm, correspond in Brazil to Cananéia transgression, Penultimate transgression or barrier III, defined respectively to coastal plains of São Paulo State (MARTIN \& SUGUIO, 1976), Bahia State (BITTENCOURT et al., 1979) and Rio Grande do Sul State (VILLWOCK, 1984).

Further knowledge of the upper Pleistocene hydrodynamic characteristics (waves, tides and alongshore currents, winds) is needed to understand the older coasts development processes, through erosive and depositional events. In the same way, subsurface stratigraphic data and absolute dating (for instance - obtained by thermo luminescence method) will confirm the characterization of the nonoutcropping Pleistocene intertidal marine, lagoon and eolic deposits.

\section{AcKNOWLEDGMENTS}

Thanks are due to the Department of Geosciences and Postgraduate Program in Geography of the Federal University of Santa Catarina for the opportunity to develop this work and to Jasiel Neves for the drafting of the figures. 


\section{REFERENCES}

BIGARELLA, J. J. Structures developed by the dissipation of sand dunes. Bolm paraná. Geosci., v. 33, 1975.

BITTENCOURT, A .C. S .P.; MARTIN, L.; VILAS-BOAS, G. S.; FLEXOR, J. M.. Quaternary marine formations of the coast of the State of Bahia, Brazil. In: INTERNATIONAL SYMPOSIUM ON COASTAL EVOLUTION IN THE QUATERNARY, São Paulo, 1978. Proceedings... São Paulo: Instituto de Geociências - USP, 1979. p. 232-253.

BUTLER, R.W. The concept a tourist area cycle of evolution: implications for management of resources. Can. Geographer, v. 24,n. 1, p. 5-12, 1980.

HORN FILHO, N. O. O Quaternário costeiro da ilha de São Francisco do Sul e arredores, nordeste do Estado de Santa Catarina - aspectos geológicos, evolutivos e ambientais. Porto Alegre. 312p. Tese (Doutorado em Geociências)- Instituto de Geociências, Universidade Federal do Rio Grande do Sul, Porto Alegre, 1997.

HORN FILHO, N.O. Setorização da província costeira de Santa Catarina em base aos aspectos geológicos, geomorfológicos e geográficos. Geosul, v. 18, n. 35, p. 284-288, 2003.

HORN FILHO, N. O.; DIEHL, F. L. Geologia da planície costeira de Santa Catarina. Alcance, v. 1, n. 1, p. 95-102, 1994.

HORN FILHO, N.O.; DIEHL, F.L.; ABREU DE CASTILHOS, J.A.; GRÉ, J.C.R; HOERHAN, E. DE L. E S. Geoarchaeological evidences of the coastal Quaternary of the São Francisco do Sul island, Santa Catarina, Brazil. In: ARGOLLO, J.; MOURGUIART, PH. (Ed.). Climas cuaternarios en América del Sur. La Paz: Editions ORSTOM., 1995. p.111-119.

HORN FILHO, N.O.; DIEHL, F.L.; AMIN JR., A.H. Quaternary geology of the central-northern coastal plain of the Santa Catarina State, southern Brazil. In: INTERNATIONAL GEOLOGICAL CONGRESS, 30, Beijing, 1996. Abstracts... Beijing: IUGS, p.202

HORN FILHO, N. O.; ABREU DE CASTILHOS, J.; GRÉ, J. C. R.. The coastal Pleistocene of the State of Santa Catarina, southern Brazil. In: RABASSA, J.; SALEMME, M. (Ed.). Quaternary of South America and Antarctic Peninsula, v. 10. Rotterdam: A.A. Balkema, 1997. p. 45-54.
MARTIN, L.; SUGUIO, K. 1986. Excursion route along the coastal plains of the states of Paraná and Santa Catarina. In: INTERNATIONAL SYMPOSIUM ON SEA LEVEL CHANGES AND QUATERNARY SHORELINES, 1986. São Paulo: Inqua, 1986. 124 p. (Special Publication n. 1)

MARTIN, L.; SUGUIO, K.; FLEXOR, J. M.; AZEVEDO, A.E.G. DE. Mapa geológico do Quaternário costeiro dos estados do Paraná e Santa Catarina. v. 28. Brasília: DNPM, 1988. Série Geologia, Seção Geologia Básica, v. 28, p. 1-40. 2 mapas.

SILVA, L. C. DA. Os terrenos metamórficos de médio a alto grau do Pré-Cambriano de Santa Catarina. In: CONGRESSO BRASILEIRO DE GEOLOGIA, 33., Rio de Janeiro, 1984. Anais... Rio de Janeiro: SBG, v.5, p. 2590-2597, 1984

SPERB, R.M.; MENEZES, J.T.; ABREU, J.G.N. DE; KLEIN, A.H. DA F.; HORN FILHO, N.O.; CALLIARI, L.J.; SIEGLE, E. São Francisco do Sul island field trip guide. In: INTERNATIONAL COASTAL SYMPOSIUM, 8, Itapema, CERC, 2004. $32 \mathrm{p}$.

SUGUIO, K. 1992. Dicionário de geologia marinha: com termos correspondentes em inglês, francês e espanhol. São Paulo: T. A. Queiroz, 1992. 171 p. (Biblioteca de Ciências Naturais/USP, v.15).

TRAININI, D. R.; DIAS, A. A.; KREBS, A.S.J.; SOUZA, E. C.; CAPELETTI, I.; TONIOLO, J. A.; SILVA, L. DA; SILVA, M. A. .. Projeto Vidal Ramos - Relatório Final. Porto Alegre: DNPM/CPRM. v.1, 1978. 303 p.

VILLWOCK, J. A. Geology of the coastal province of Rio Grande do Sul, southern Brazil. A synthesis. Pesquisas, v.16, p. 5-49, 1984.

VILLWOCK, J.A.; TOMAZELLI, L.J.; LOSS, E.L.; DEHNHARDT, E.A.; HORN FILHO, N.O.; BACHI, F.A.; DEHNHARDT, B.A. Geology of the Rio Grande do Sul coastal province. In: RABASSA, J. (Ed.). In: INTERNATIONAL SYMPOSIUM ON SEA LEVEL CHANGES AND QUATERNARY SHORELINES. Proceedings... Quaternary of South America and Antarctic Peninsula, v. 4:79-97.

(Manuscript received 12 December 2006; revised 13 August 2007; accepted 14 February 2008) 